\title{
AKT1 NM_001014431.1:C.49G>A
}

National Cancer Institute

\section{Source}

National Cancer Institute. AKT1 NM 001014431.1:C.49G>A. NCI Thesaurus. Code C98305.

A nucleotide substitution at position 49 of the coding sequence of the AKT 1 gene where guanine has been mutated to adenine. 